\title{
In spaces in between-From recollections to nostalgia: Discourses of bridge and island place
}

\author{
Jana Raadik Cottrell \\ Centre for Blue Economy of Tallinn University of Technology, Estonia \\ Colorado State University, USA \\ est.jana@gmail.com
}

Stuart P. Cottrell

Colorado State University, USA

stuart.cottrell@colostate.edu (corresponding author)

\begin{abstract}
Creation of a terrestrial connection to the mainland from Saaremaa Island (Estonia) has been discussed among politicians, scientists and the general public for the last decade. A fixed link has been a dream, hope, and fear in a situation where the island faces enormous societal changes in a rapidly developing young capitalist country. Islanders and visitors feel threats to their home place with or without the bridge. This paper explores public discourse of textualized landscapes as context-dependent multiple realities. Questions related to the perceptions of change of material landscapes as well as symbolic meanings of lived environment in the transition and rhetoric of everyday spatial practices are examined. The rhetorical 'journey' of a planned terrestrial fixed link (a bridge from an island to the mainland) is followed. Materials from an online public forum from five years related to the topic and approximately 120 online articles with more than 1800 comments from the general public were examined to reveal major themes of discourse on island place, landscape of identity as well as possible transformations of related concern. Idealized landscapes of a nostalgic past are voiced equally yet differently among political powers, islanders themselves and tourists.
\end{abstract}

Keywords: bridge, home, islands, landscape, nostalgia, place identity

https://doi.org/10.24043/isj.133 • Received May 2020, accepted October 2020

(C) 2020-Institute of Island Studies, University of Prince Edward Island, Canada.

\section{Introduction: A proposed bridge from the mainland to Saare County}

Saare is the westernmost county of Estonia, consisting of five major islands and numerous islets (Figure 1). Saaremaa is the largest of these islands with a population of approximately 33,000 and has the only city in the county. Historically the area has been a border zone between West and East. In 1940, Estonia was annexed by the Soviet Union, and Saare County became a restricted border zone until the re-independence of the Estonian Republic in 1991. Fifty years of limited access contributed to the undeveloped coastline, ethnically homogenous population, and limited development pressure on natural resources, with the exception of 
moderate agricultural activities (Raadik Cottrell, 2010). The landscape of the islands changed during Soviet occupation due to the changed production modes (shift to collective farms), nationalization of land, and restricted private access to the sea. The islands, however, maintained a unique combination of traditional villages with small private farming and moderate-sized collective farmlands. With a population of $99 \%$ ethnic Estonians, the islands became an oasis of the nation, as the Soviet assimilation politics were not practiced in this border zone. Travel to the islands by non-resident islanders and other Estonians was prohibited without a special invitation from local inhabitants and was limited to two weeks to one month per invitation. Travel to the islands for those who had acquaintances or relatives there became more like a visit to the 'homeland' since the hosts were responsible for their guests.

The modern lure of the islands gained its potency from the restrictions, and the islands became a desired 'dreamland' for many Estonians. The passage of time on the islands and the security they provided were different from the 'restless' world outside. Local semi-cultural landscapes and customs became symbols of Estonia's past and were visualized in poems, paintings and popular songs. Lennart Meri, a well-known intellectual and humanist and first president of the newly independent country, wrote the book Silver White about the importance of the island place in European cultural history, which increased visits to the land of the 'mythical Thule Lake'. The 'Saaremaa Waltz', a song written by a local poet and made famous by a well-known Estonian singer during the era of Soviet occupation, echoed the beauty and resistance to alien powers and became a powerful representation of the place in attracting many Finnish tourists (Sooväli, 2004). 'An island where time rests' is a promise given to visitors by the tourism board while crossing the strait between the mainland and Saare County. Proposals for a bridge to the mainland originated in the 1930s (from the era of the first Republic) and have been anchored in political debates since the early 1990s. Since then, the bridge has been a source of political debate and electoral promise for many locals and domestic visitors desiring quick and stress-free travel (Raadik Cottrell, 2010; 2017).

This paper examines what entered the online public debate space about a possible future bridge to island from mainland Estonia to Saare County. It aims to understand how "slow rhetorical transition" (Sloop, 2004, p. 19) works through public debate and how changes in meanings are contained by ideological practices as well as anticipated by the general public. Articles in online newspapers and online forums are open space for public communication in Estonia. This online public debate space is created in connection with free speech and political agendas and works as a space of fleeting encounters. Online public debate in its anonymity is not a public debate space in its classic form; this is space where ideas are rendered through virtual bodies in circular real time. We examined the online public debate from the question of how desires and fears of a bridge are articulated by media-in national and local newspapers, as well as their communicative counterparts-online forums and debates from the general public as determined via a critical discourse analysis.

This research explores public discourse of textualised landscapes as context-dependent multiple realities. Through a content analysis of existing research and a synthesis of empirical data in the discussion, public discourses of readings about lived landscapes were examined. Questions related to the perceptions of change of material island landscapes as well as symbolic meanings of lived environment in the transition and rhetoric of everyday spatial practices were investigated. For this review, selected texts from the fields of sociology, philosophy, political theory and rhetoric lead the discussion, while analyzing empirical data from online public forums. 


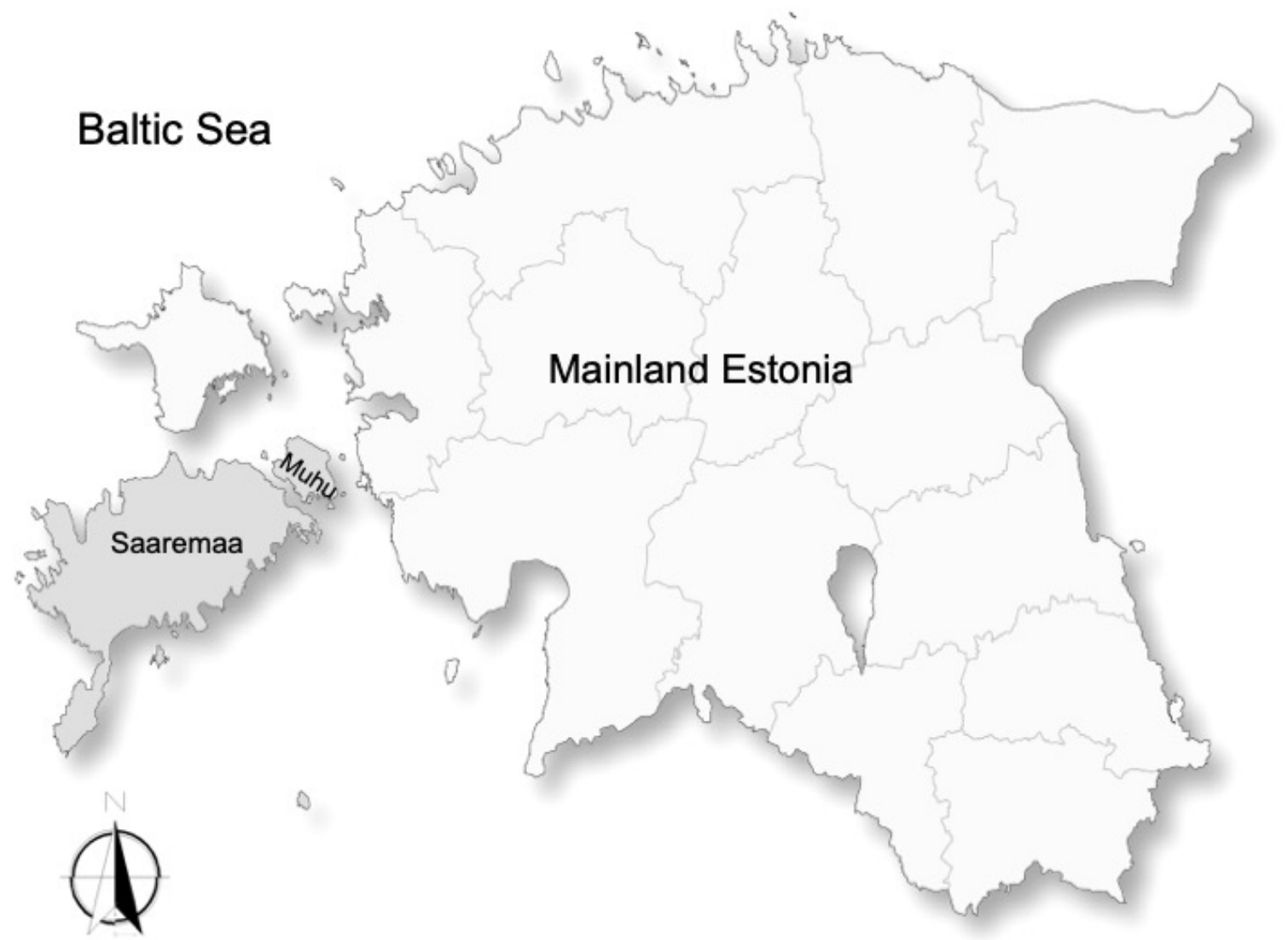

Figure 1. Saaremaa Island, Saare County, Estonia (shaded grey). Source: Raadik Cottrell \& Cottrell, 2020.

\section{Methods}

Empirical data of interest for a content analysis through the lens of a critical discourse analysis (Yell, 2005) came from online media publications and online public forums reflecting views on the developmental plans of the island place of Saare County, Estonia. This paper follows the rhetorical 'journey' of a planned terrestrial fixed link in the form of a bridge from Muhu island to mainland Estonia. Materials from an online public forum from a five-year period (2002-2007) related to the topic, reviewing approximately 120 online articles with more than 1800 comments from the general public, were examined to reveal major themes of discourse on island place, landscape of identity as well as possible transformations of related concern. We argue that the online public discourse surrounding the possible building of the bridge can be seen as a site where meanings of an identity of island place are struggled over in contemporary Estonian society, drawing on nostalgic renderings of home. Critical discourse analysis is used as an approach to draw together the perspectives of 'language in use', and also Foucault's (1980) perspective on discourse. The paper draws on and also overlaps with critical linguistics and social semiotics (Yell, 2005). 


\section{Predominant discourses in the media}

\section{Landscapes of recollections}

The idea of a fixed connection of the island of Saaremaa with the mainland brought up by the new political structure of a free Estonia is moving slowly but steadily through a public realm, with reflections found in media. 'Crossing that bridge' is a theme of development and notion of progress in the present-day political landscape of Estonia, where democracy was restored under the slogans 'Clear that place!' and 'A fresh start'. Along with the political system, physical places were restructured. Nostalgia towards the past found its legalized existence in legislative practices of restitution, touching every citizen of the country. Political restitution cut through spaces, leaving places to struggle with materiality created in the 'inbetweenness' of 50 years. Estonia claimed its' second 'era' of freedom on a political restitution of first period of independent Estonian Republic, interrupted by the annexation of Baltic states by the Soviet Union in 1940. With the restitution process, private property that had been nationalized in 1940 was returned to its former owners or their relatives, creating however another social inequality. Quite a number of 'new' former owners of land and private property are living permanently abroad. Collective farms as forms of socialist economy were demolished, and private farming was stimulated. In a situation of lack of financial resources and collapsed former market, a majority of these private farms failed to survive. Half-legal timbering and selling pieces of land (mostly coastal land) to foreigners has become the only form of income for many local landowners. "Spatial anxieties', the fears and uncertainties about place, belonging and recognition" (Allon, 2000, p. 275), emerged along with a shift in political and cultural discourse. "Illegible landscapes" (Allon, 2000) increased the desires for home, suddenly lost in this transition from "socialist past" to "past idealized." The landscape of the island as memorized by Estonians through the centuries has started to evaporate along the way. Traditional landscapes of coastal meadows, vibrant rural villages, dispersed grain fields with blooming flowers, and rich forests entered the era of desire for extensive logging, decline in rural life, and divisional landscapes of summer cottages (Kaur, Palang, \& Sooväli, 2004). The past idealized has suddenly turned into a 'present unwanted'.

\section{Political landscapes of nostalgia}

The notion of a bridge to the mainland entered public debate in 1997, shortly after the 100year anniversary celebration of a causeway between Muhu Island and Saaremaa, a terrestrial connection built to improve the infrastructure inside island space in the late- $19^{\text {th }}$ Century. Fantasies and dreams from 100 years ago of connecting the islands to the mainland were memorized and articulated within the context of a fixed link. The centennial celebration of the causeway gave birth to a wish for a new memorial to political will and power. Memories of past dreams were turned into necessities of the present. Island place suddenly turned from a 'nostalgic island lure' to an 'island without a terrestrial connection', a place without equal possibilities for a future. Representatives of the County Government framed a 100-year old dream within present-day political reality as a sign of the development and progress for which islanders had long been fighting for, emphasizing the great past of islanders' free will and rebellious minds. It was suggested that now, with the free Estonia, dreams that had long been repressed under Soviet occupation could finally come true. Rhetorically justified by notions of 'development' and 'progress', a terrestrial connection to the mainland has become a symbol 
of hope to all present troubles of 'lost home' the island community faces today. This almost Utopian state of 'lost past-hoped future' that might come with a fixed connection to the mainland has been fed by politicians fighting for their positions in Parliament, and has become a precious election pledge, carefully maintained and passed from election to election, from one political party to another.

Volĉic (2007, p. 21) argues that as "socialism relied on the promise of Utopia yet to come, capitalism feeds on a sense of loss." Hopes, desires and fears connected with the proposed bridge feed on nostalgia of lost home. Yet that nostalgia has different contextuality and different articulation among different political parties as well as the general public. Examining the amount and content of news regarding the 'Great Dream' of a fixed link ('Great Dream' is a term first used by an Estonian daily newspaper in June 2003 (MM, 2003, June 6) in official online news, it is important to mention that the pattern and tone of news varies before, after and in between political elections. Between elections, discussions about a terrestrial connection focus more on opinions from scientists and environmental organizations or on discussions surrounding possible forms that the connection may take, with notions of the need for additional research and possible environmental impacts. In comparison, electoral promises are concrete and clear: "Saaremaa Fixed Link is knocking on the door of European funds" (MM, 2002, September 05), "The route of the million dollar bridge is placed on a map" (PM Online, 2002, October 12), "Bridge is coming no matter what" (Aardam, 2007, March 01), "Bridge will be in 2015" (MM, 2007, March 27). Articles prior to the elections do not link actual political figures to promises made in support of the bridge; instead the promises are linked to the political parties. In contrast, opposition to the bridge is personalised, e.g. "Tarvis: Centre Party has not discussed the fixed link" (Kuivjõgi, 2003, February 07).

After the elections, promises shift to more doubtful ground: "The top official of County Government: No need to hurry with the bridge" (Sepp, 2004, October 06). Doubts are presented through individual voices, becoming more similar to personal statements: "Savisaar: Next government should work on the fixed link" (MM, 2006, June 06). Political promises themselves are consequently forgivable towards their own memory. The same political figures tend to shift to the next round of dreams and promises while forming coalitions with political 'enemies' of the past. Ideas concerning the bridge are in political terms equally useful to everybody, and very few parties do not use it as at least one of their political statements. Differences, however, lie in the imagined future connected to the proposed bridge. The Reform Party promises that the bridge will lead to quick connections and to development, prosperity, and entrepreneurship. Emotional statements are at work here, with emphasis on rapid 'freedom of movement' and 'home'. However, dreams of home as successful and competitive, as a place worth living in, are located outside the present. Rapid connection 'in and out' is the main argument presented in a situation in which thousands of islanders work off island due to lack of employment on the island, a situation created by rapid changes in society. Saaremaa has for centuries relied on agricultural production as its main form of employment. With the rebirth of the Estonian Republic, collective farming as the main form of agricultural production from the Soviet era was replaced by private farming. Politics of development are so far concentrated around the capital city Tallinn, where financial power and turnover are creating an unbalanced economic and social situation. Tallinn has become main attractor of labour. 
An article on "Progress and success presume equal opportunities" (Lember, 2007, March 01) asserts political powers for the bridge: "Equal opportunities start from a good connection: all people must have an opportunity to travel safely and quickly from one place to another." The bridge is a promise of easy travel between "city and home" (capital city and island respectively) for both permanent island residents and for those who moved to the mainland but retain second homes on the island. 'Home' here is opposed to the city. With a notion of quick and safe connection, however, proponents of the idea have seemingly eliminated other options for better connections, such as a tunnel, which would probably provide a more stable connection than the bridge, bearing in mind the climate in this region. While discussing possible connections between the island and the mainland, politicians made statements like "Connection with mainland is a question of everybody's inner feeling" and "Tunnel is a foreign and uncanny idea to islanders" (MM, 2004, May 22). When the bridge concept entered the public realm, the first drawings of the Big Dream as a cable-stayed bridge were posted online and became the banner of the primary local newspaper. Aesthetic visions of a bridge rising up high were imposed. Emotions such as "Bridge is a magnet, not the tunnel" (MM, 2004, May 22), "We do not want just any kind of connection" (MM, 2004, May 22), "Bridge is attractive" (Neudorf, 2005, July 05), and "Opportunity to create island Wanderlust" (Neudorf, 2005, July 05) were strongly present in political comments. This was despite official statements from the government that continued to stress that a final decision had not been made.

Emphasizing the bridge as a place of wonder, the bridge's most vocal proponents have not accepted a free cantilever concrete bridge as an option, even though this has been proposed by the Danish experts, highlighting the bridge's link between the East and the Trans-European Transport Network as a transit corridor (EPLO, 2005, July 01). Opponents of the bridge (Green Party, People's Party Moderates, Centre Party in general) warn against it as a hope for a quick solution for deeper economic and social problems: "It is possible that bridge does not change most people's lives for the better" (Ammas, 2005, September 27). Instead of looking at the easy travel and "in and out" possibilities, they emphasize looking inside the home-place: "Bridge or local community centre?" (Õunapuu, 2007, January 31), and "The Island does not survive under increased traffic and the place it creates" (Lember, 2007, February 02) are among the concerns that have been raised. As political parties in present-day Estonia are symbolized and positioned in an oppositional manner and not along a continuum of diverse values, little else is articulated politically in between the so-called retrograde nostalgia of the Soviet past and the progressive (nostalgic) dream from past to future. The Big Dream, reborn in 1996 with the help of politicians, attempts to fit within the changing landscape of nostalgias of home of islanders, as well as tourists, in their everyday lives of 'heterotopias' (spaces that have more layers of meaning and relationships to other places than immediately meet the eye) (Foucault \& Miskowiec, 1986).

\section{Landscapes of nostalgias and desire}

Many islanders commute between the island and the mainland, trying to combine their desire for a higher income offered by better work opportunities outside, and a nostalgic island place of childhood, within an enlarged place and space of everyday connections. Families stay on the island, which offers a cleaner and safer environment as well as a closer community, while many men start their journey to the mainland at the beginning of each week. The struggle 
between a desire to have a life as 'elsewhere' outside of the island and to keep home on the island is becoming more complicated as increasing pressure of travel to the island creates traffic problems. Thousands of tourists, as well as islanders, permanently living on the mainland, desire to travel to the island on weekends to experience the lure of solitude (Raadik Cottrell, 2010; 2017). Travel by boat for many tourists is one of the components of their desired experience; the island being a place disrupted by the sea, and a place offering a different bodily experience of traversing through a landscape of the sea (Raadik Cottrell \& Cottrell, 2015, 2019; Sooväli, 2004; ). For most islanders, as emphasized in their online comments, the ferry connection is more of a necessity, an imposed 'everydayness' of the island life. The ferries connecting the island to the mainland are nicknamed 'slave boats', a term used both by the general public and politicians. Hundreds of islanders go to work on the mainland, using primarily the ferry connection. The boats take them away from their home (the island) to a place of work (the city). Another connotation might be related to the ownership of the ferry line, which belongs to the wealthiest person on the island. Connection with the mainland was perceived as controlled and influenced by one person and with a sinful way of making money off of islanders' nostalgias of home.

Only a few of the scientific studies done concerning the island were included in the online debate forums or newspapers, with most written in a political context (Raadik Cottrell, 2010). "Why and whether Saaremaa is attractive" (MM, 2003, May 22), an article based on study of landscape preferences of islanders and tourists, casts doubt on the rationality of a bridge as a lifebelt from a "dark future" of peripheral status. Research concluded that the island's present-day peripherality is relational and a "myth" propagated by reformist politicians. Fear created by politicians of being displaced on the "other side" of development if a bridge is not built makes many islanders desire the bridge. Meanwhile, as indicated in the study, everyone desires the same landscape: idyllic, insular, in reality becoming more and more just a "construction of the mind." Disappearing traditional landscapes are an "embodied witness" of shifting values, presenting lifestyle as elsewhere. The "ideal home of childhood" becomes nothing more than "a well-sold myth," intensively exploited by developers and reformist politicians for marketing and political purposes.

One study of the bridge discussed online noted the need for an "internal" view of developmental logistics. "I am not against the bridge, but against the false expectations connected with the bridge," stated Enno Lend in his doctoral dissertation; "it is a selfdeception to think that all the negative impacts come from a connection by ferries and insularity" (Lember, 2007, March 05). Scientific studies, mostly done by non-islanders, are received with skepticism by islanders, who see them as lacking specific solutions for development and representing "pseudo-sciences" or "political custom work."

\section{Landscapes of home from in and out}

The fixed link has steadily entered public notions of home and everyday life as islanders. Some islanders can no longer imagine their future without a bridge, and some can no longer imagine it with a bridge. A majority of islanders probably feel somewhere in between, trying to fit their lives within the changed/unchanged conditions. A majority of the online information and comments related to the bridge came from local newspapers, probably mostly reflecting the views and ideas of islanders. Compared to comments in national newspapers on the same issues, those from local newspaper forums with a pro-bridge argument are more emotional. 
Arguments mainly use notions like "everyday" and "life as elsewhere," when it comes to a life on the island. The bridge as a symbol of progress finds its reflection in comments as a right to be "modern" and "white":

Do not islanders have a right to be modern? Some people think we should live here and follow the rules of the past. Who is an islander, and how should it reflect on our everyday life? We everyday islanders want to live here and work. Bridge is just needed!

I need to feel myself as a white person, free to go where and when I want to.

In the rhetorical construction of whiteness, freedom and whiteness are used as synonyms. This strategic rhetoric, as noted by Nakayama and Krizek (1995, p. 295), functions to "re-secure the centre, the place, for whites." Islanders coping with the enlarged place and space of their everyday lives when commuting between the island and the mainland are forced to redefine the centre. For some people, the bridge seems to symbolize a fundamental basis for their lives on the island, almost as an integral part of an island as a physical or mental reality, with comments like: "Go and live yourself on an island without a bridge!" An island without a bridge begins to symbolize "a closure," a place simply for "pure nostalgia."

My opinion is that if there will be no bridge, we can lock the door of the island and throw the key into the sea. It would be so nostalgic to sail sometimes to the island!

Peculiarity and distinctiveness of an island is in some comments declared as "nonsense" and "nostalgia of outsiders." An existing connection with the mainland via ferry is considered part of that nostalgia:

Bridge is needed! So called "lost of island peculiarity" and all the other nonsense is preached by "mainland fools" and others who are connected with the Ferry Company.

Concerns expressed in the press about the possible future of the island becoming nothing more than a mere transit corridor for Russian oil after the bridge is built seem to show a change in meanings about the island as a home. For some, the notion of home seems either fragmented out to or unified into a larger context, as their place of dwelling gets extrapolated from the island place as a home:

Most important is that bridge will come. I do not care if it is meant for a transit for Russians, Estonians or Jews [...] I just want to live here.

In contrast, opponents to the bridge see it as a political matter and form their arguments around the "distinctiveness" of their home-place, the island. Instead of looking externally for solutions, they see internal problems that the bridge will not cure, with comments such as: "Bridge is not important, but how place is developed and managed from the inside." A metaphor of "door" is used to describe the connection to the mainland, emphasizing the aesthetics of the bridge like "a beautiful door": "Beautiful door is not a key 
to success, important is what is inside. Bridge is a lazy solution." Several comments imply that the bridge is connected to political games, with negative consequences for the island place. The bridge is labeled a "monument," "extension of a penis," "political genre of false expectations," and a "source of energy for a perpetual movement in political games," turning the island from a "green natural pearl" into a "car/ mass tourism playground" and a "metropolitan amusement park." Questions like "What is this bridge reactivating? Staying or leaving?" and "What kind of bridge will save the peripheral regions on the mainland?" are asked to pinpoint that islanders should protect and cherish what they have as people living on an island. In contrast to this argument, others fear that young and educated people will leave the island forever if there is no bridge:

Young people move to the place where higher salary and better opportunities of personal development are offered, they are not interested in wide open paved roads. They will return to their home if they are raised to cherish home along with cherishing themselves, home as it is, not the paved road to the home.

Many share their general disappointment with politics, labeling the issues surrounding the bridge as "self- deception," "shameful" and "fraud":

The question remains: Who is cheating whom? Is our country cheating islanders that bridge is not needed just for a transit corridor or European Union that bridge is meant for a transit? Both ways it is just a dirty game.

Comments from online national newspapers are more dispersed between the different issues and less supportive of the bridge concept. The majority of the comments shared the view that islanders will lose more then they will gain, that something valuable will be lost that cannot be measured economically. Comments include: "People tend to forget the real price," suggesting that notions of progress and development do not necessarily entail 'things getting better'. References are made to memory, as bridge plans remind us of the many great plans of the past Soviet era "to turn the flow of the great Siberian Rivers". The terrestrial connection was noted to be a loss of place as a valued combination of people and landscapes: "A lot of the sense of island place is already turned into memory, and now you want to take that away as well".

Much irony was expressed online regarding the continual debate about the terrestrial connection from the mainland to the island with comments such as "Bridges to all islands, because people love islands!" or "Let's sell the Island to Latvia, they do not have any!". Political manipulation is sensed not only in the games played for the electoral seats in Parliament although this is strongly articulated through comments such as "Bridge is used as a political argument, this lifesaving straw when all the other ones are used up," "Experts know that the bridge is just utopia, but before elections this was not convenient 'news' to declare. Let's beat the drum, and after four years again," or "After the elections after two or three years in power politicians will find ways to ignore promises. Then they will take a short break, rephrase the arguments and start it all over again". Another layer of political game is sensed in the placing of a "future blame" on the general public's shoulders: 
If the bridge was so vital to the existence of the island, it would already be here!

No one would ask for the pros and cons. It is sad how they manipulate via public emotions, and finally take their own decision anyway. But yes, the 'people' are still an important component here, because somebody must be present to blame, if that bridge will not be 'the dream come true' if finally materialized. Politics try to manipulate us via sincere and trustworthy dialogues. Let's forget that bridge! Get out and listen to the sounds of nature and don't be just the tools in the hands of politicians.

\section{Discussion}

"We have said that space is existential; we might as well have said that existence is spatial” (Merleau-Ponty, 1962, p. 293)

\section{Landscape as place and space}

The volatile constructions of our spatial existence are practiced upon a land and find their reflection in a landscape. Island landscapes such as Saaremaa in Estonia can be viewed within a broader context as common property (Kaur, Palang, \& Sooväli, 2004; Linehan \& Gross, 1998). Landscape as offered by Saaremaa Island itself thus becomes primarily a "visionscape" open to everyone as a public good made more accessible by a bridge to the mainland and a basis for experiences, recollections and nostalgia. Landscapes are one source and tool of identification (Blickle, 2002; Cosgrove, 1985; Häyrynen, 2004; Kaur, Palang, \& Sooväli, 2004; O'Keeffe, 2007). Berleant (1997, p. 12) states that landscape, reflecting the experience of an immediate location, is an individual environment, an embodied experience:

Its peculiar features embodying in a distinctive way the factors that constitute any environment and emphasizing the human presence as the perceptual activator of that environment. We can express this somewhat differently by saying that landscape is a lived environment.

According to Berleant (1997), in continuity lies identity, although continuity is not a mark of a fulfilling unity of body and environment; neither is continuity always positive, nor does it deny distinctions and differences. The argument for continuity rests within an awakened sense of experience. One's sense of continuity is both perceptual and material. Berleant (1997, p. 110-113) continues, "continuity epitomizes the fullness of aesthetic engagement [...] But at the same time, and as part of this embodied experience, we carry our knowledge, beliefs, and attitudes with us, for these participate in the process of experience and enable us to structure and interpret it." Landscapes are sustained through communication processes, stabilized and harmonized through shared activities and common language (de Certeau, 1984; Thwaites, 2001; Tuan, 1977, 1980, 1991). As noted by Tuan (1980, p. 6) "people are constantly making and unmaking places by talking about them [...] in a sense, a place is its reputation." People are in various ways affectively attached to places (Grossberg, 1996), especially islands. Places become multilayered worlds of social meanings, filled with needs and desires (Allon, 2000; Dickinson, 1997; Parts, 2004; Stokols, 1981), and offer 
experiential opportunities to wander on the landscapes of perceived and imagined spaces such as that found in island places (Berleant, 1997; Brocki, 2008; Burgin, 1996; de Certeau, 1984; Dickinson, Ott, \& Aoki, 2006; Hong, 2020; R. Kaplan \& S. Kaplan, 1989). Island places as postmodern landscapes, which in their desire to maintain or reference the fragments of a social, economic, cultural and ecological past while embracing the equally diverse needs of potential users, draw our attention to memory places such as places of insularity, peculiarity, belongingness, "those sites where the cites necessary for the invention of self are located" (Dickinson, 1997, p. 21). Dickinson (1997) emphasizes the role of memory as more than just mental operation, but a spatial and bodily operation placing both individuals and landscapes within a "stabilizing past", which is demonstrated in this study of nostalgia and the media discourse of connecting Saaremaa Island to mainland Estonia via bridge. Recollections and dreams constantly dismantle and recreate the borders of this space of identity-making.

Identities of places and people are in a constant state of becoming through semantically overloaded nostalgias and total dissolubility of boundaries between 'Us' and 'Others' (Duszak, 2002). Nostalgia can be defined through different emphases on its outcomes. Volĉiĉ (2007, p. 25) argues that nostalgia establishes emotional relationships between an individual and the past insofar as "nostalgia complements rather than replaces memory [...] As much as nostalgia expresses a love for the past, it can also serve as a vehicle for xenophobia, anger, fear, hatred, and anxiety." As much as that anxiety and hatred can be addressed towards the Other as an obstacle to achieve a desired idealized version of the past, it can equally work against the very same past as a tool of self- deception towards an idealized "past-future home." This "nostalgia of home" encloses itself in a fantasy in various ways. This sense of alienation, this search for the past through our own images and stereotypes about the past, is fostered by contemporary capitalism (Jameson, 1997), as evidenced in the media about Soviet past, newly regained freedom, and renewed dreams about building a bridge to mainland Estonia to enhance mobility, accessibility and the potential for economic growth on Saaremaa. Nostalgia for home can paradoxically equal fantasies of an 'absent present' (Ritivoi, 2002) in a home place such an Saaremaa as well as about the 'becoming present' of home as a global citizen. Consequently, the search for a 'lost home' might be the hope to find a solution through better connections to external space or, on the contrary, a desire to rediscover home inside a home place. Nostalgia for home finds its way in-between landscapes of recollections and desires (Raadik Cottrell, 2010, 2017), as solitude in insularity and global openness.

In a contemporary world, the construction and meaning of places arise primarily because of developments, disruptions of notions of place due to intensified spatial extensions of social relations, time-space compression, and so forth (Giddens, 1991; Massey, 1995). Place identities are frequently contested as meanings of place vary across different groups and take the form of a battle over the material future of the place based on rival interpretations of the past (Massey \& Jess, 1995). Any of these contested claims are, however, made in particular space-time, which is in constant change, with the result that claims are subject to change as well (Massey \& Jess, 1995). Landscapes have proven a useful way to present on a larger scale the metaphor of identity, not only at an individual level but also at a national level (Bell \& Lyall, 2002; Blickle, 2002; Häyrynen, 2004; Kaur, Palang, \& Sooväli, 2004). Rapidly changing political, economic and sociocultural conditions find their reflections in landscapes.

Saaremaa Island in Estonia is no exception. Traditional landscapes with distinctive structures, with clear relations between the composing elements, and with significant natural, 
cultural and aesthetic values that evolved through slow historical processes face degradation. These processes receive affective responses from people, as the landscape is symbolically significant in their identity process. Landscapes of memory gain importance as valued thresholds in the process of fixing otherwise-fragmented identities. Landscape appreciation for a transforming information-oriented society is based largely on holistic value, where historical, aesthetic and identity values are increasingly intertwined (Dickinson, 1997; Dickinson, Ott, \& Aoki, 2006; Leung et al., 2017; Kaur, Palang, \& Sooväli, 2004). As a shared space and place, landscapes of memory are sites for discourse, where professed views draw on the same narrative values of home while resulting in different outcomes. Memories and nostalgias for home are effective tools in the politics of resistance as well as in "explicit", "regular" politics (Thrift, 2004). Our place-bound relations have not changed to a mere "space of flows" in contemporary society, in which the process of movement in that "futurepast of present" (Rossiter \& Cooper, 2005) has changed. The public sphere in a net of new technologies, subjects, networks and institutional forces has opened a new political arena for affective politics as a counterpart to the regular politics.

\section{Implications}

O'Keeffe (2007, p. 4) argues for a constructivist understanding of landscape, which claims landscapes to be "the product of mindscape"-inalienable from the realms of cognition and mnemonics and from consciousness as a whole, "including 'non-consciousness', in the sense of Bourdieu's 'habitus'." The same goes for landscapes' democratic value, as "everybody knows, possesses, and partakes in 'landscape"' (O'Keeffe, 2007, p. 4). Thus the landscapesituated responses (of resistance and compliance) to authority articulated in and over the landscape are seen as "acts of landscape-construction and identity-formation in their own right" (O'Keeffe, 2007, p. 4). Studies of new media can open new layers of meaning-making in the space of hypertext. Exploring "marginal" media and communication practices (internet chat, etc.) as possible sites of subjugated knowledge (Yell, 2005) helps us understand and see the "slowly turning narratives" of society. In this processual aesthetics, where aesthetic cues as cultural signifiers are mapped in spatial play, the political process that matters to people may be open (Thrift, 2004; Viola, 1995, 2003). As noted by Thrift (2004, p. 74), without this kind of affective politics, what is left of politics will often be the kind of macho program-making that emaciates what it is to be human-because it is so sure it already knows what that will be.

A social semiotic concept of 'text' does not see text only as a product, but as a process (meaning-making/semiosis) (Yell, 2005). Texts as 'sites' for meaning-making are also tracks of this process of meaning production. Text, as noted in this study, is not just an arrangement of signs, but jointly produced by participants of communication (Yell, 2005). A social semiotic approach blurs the borders between receivers and producers of the text, while incorporating the larger social and cultural context. Social semiotics does not maintain a distinction between the 'langue' (system of language) and 'parole' (use of language) in Saussurian terms; its fundamental unit of meaning is text, as a social act and communicative practice (Yell, 2005). Discourse, such as that concerning bridge development, is a contested term as stressed by Yell (2005, p. 22), slipping between "a concept of 'text as a social practice' and 'power/knowledge' relations." She argues that meaning-making is never purely just an expression, yet is always interlinked with power/knowledge. Foucault's (1980) concern about discourse has always been related to identity and marginal knowledge, regarded as trivial or non-serious. Foucault's 
standpoint, however, was that identities were defined and knowledge organized through everyday practices. According to Yell (2005) and Rossiter and Cooper (2005), the supposedly marginal and non-serious forms of communication such as text messaging, chat rooms and blogs might be viewed as sites resembling "subjugated knowledge." Following their argument, this study emphasizes the importance of online commentaries related to manifestations shared in public media. Rossiter and Cooper (2005) also emphasize the nonlinearity, interactivity, and "real-time" of those systems of relations, the constant process of "doing." Research on new media should not be considered as looking at relationships between categories and objects, rather how those categories let us know "about the 'movement' between which has emerged and the condition of possibility" (Rossiter \& Cooper, 2005, p. 104). Placing emphasis on the specifics of place and culture as evidenced by the discourse about island connectivity with larger geographical and socioeconomic space (Grydehøj \& Casagrande, 2020; Zhang \& Grydehøj, 2020) via the bridge in the new media, processual aesthetics help to articulate how those specifics are re-contextualised and reproduced within a larger relational context (Rossiter \& Cooper, 2005). With the help of Andrejevic (2002), Rossiter and Cooper argue, however, that while linking the new economy with the creation of affective identity, it is important to understand this does not automatically mean that those new encounters between subjects, technologies, networks and institutional forces represent a greater freedom or resistance. Politically fueled arguments about perceived enhanced mobility and economic benefits from the fixed link between mainland and Saare County island place follows this popular promise of a newly defined freedom and identity without a constructive critical doubt. In Andrejevic's (2002, p. 260) words, "the paradox of surveillance-based economy is that it pretends to individuals that they count $[\ldots]$ when all it really wants to do is count them."

\section{Conclusion}

This study explored negotiations over island place identity through the space of new media following the anonymous public debates posted online aroused in response to official media texts in national and local newspapers, related to the proposed bridge connecting Saare County to mainland Estonia. The online forum provided virtual space for debate about the bridge to island place from the mainland. Critical discourse analysis following the analytical dimensions of landscape, place, identity and memory through interfaces of societal changes valorized strong involvement of past in construction of views about sense of place, its identity, and future developments. The online texts were heavily based on political rhetoric of promises for a better future using a bridge to island place as the means to materialize past dreams. Political nostalgias to re-centre the island in changed sociopolitical conditions used selective memories from the past and transformed these into necessities of the present (economic development). Island of "childhood memories," a narrative powerfully present for domestic and foreign travelers, was rhetorically transformed into "island without a bridge," defining it through the absence - of equal possibilities for the future, Wanderlust, freedom of movement, etc. Landscape representations derived from "past idealized" notions come from the political manifestations "of present unwanted." Following Manichean consciousness, these manifestations lack a neutral zone, and this lack of axiological neutrality reflects on their future 
visions of the island. No alternatives were offered to the bridge as 'aesthetically pleasing' in this process of the 'aesthetization' of politics.

Public responses to the text online followed both routes of resistance and compliance, from recollections to nostalgia. Remembrance and nostalgia remapped the island in 'futurepast of present' quite differently-from motility inside of home-place to mobility out there/as everywhere. Freedom of movement envisioned through the bridge and equated with progress and whiteness offered impressions of the present island's place as pure nostalgia for outsiders, drawing a line between tourist place and lived place. In opposition was a vision of the island more attuned to experience of place, without centering planning for future environment solely on private vehicles coming to the island. References to memory linked developmental plans to a Soviet ideological past, with grand narratives and great conquest plans for nature in the name of progress. Sense of place of the island itself was perceived as revolving around past memories and the great infrastructural change (a bridge to the mainland) distinguished as an attempt to erase that memory.

The public sphere in a network expanded through new media in Estonia opened a new political arena for the discursive process of meaning-making of place. Subjugated knowledge (see Foucault, 1980; Rossiter \& Cooper, 2005; Yell, 2005) evolved through these non-linear, interactive, and real-time systems of relations in a constant process of doing, participates in the 'doing' of place in many aspects of its multiple "becomings" (Simonsen, 2008) of "throwntogetherness" (Massey, 2005). In this particular case, "past-future-present" of place was envisioned as linking multiple layers of memory (Bell, 2003; Küchler, 1999; Wertsch, 2002) with real landscapes in their materiality (Kaur, Palang, \& Sooväli, 2004). Affective responses from Estonian people showed the importance of island landscapes in their identity formation concurrently with place identity for Saaremaa Island. Landscape as a palimpsest of different social relations (including tourism) was 'read' across a continuum of recollections and nostalgia linking to other places in their absence (Soviet past, larger socio-economic space of contemporary Estonia, European Union).

\section{References}

Aardam, R. (2007, March 01). Sild tuleb nagunii. Oma Saar. http://www.omasaar.ee

Allon, F. (2000). Nostalgia unbound: Illegibility and the synthetic excess of place. Continuum: Journal of Media and Cultural Studies, 14, 275-287. https://doi.org/10.1080/713657730

Ammas, A. (2005, September 27). Saaremaa sild maksaks ligi kolm miljardit krooni. Eesti Päevaleht. http://www.epl.ee

Andrejevic, M. (2002). The kinder, gentler gaze of big brother. New Media \& Society, 4(2), 251-270. https://doi.org/10.1177/14614440222226361

Bell, C., \& Lyall, J. (2002). The accelerated sublime. Praeger.

Berleant, A. (1997). Living in the landscape. University Press of Kansas.

Blickle, P. (2002). Heimat: A critical theory of the German idea of homeland. Camden House. https://doi.org/10.3368/m.xcv.3.506

Brocki, M. (2004). Landscapes of memory: Narratives of the past places. Paper presented at Culture, Nature, Semiotics: Locations IV, Tallinn.

Burgin, V. (1996). In/different places. University of California Press.

Cosgrove, D.E. (1985). Social formation and symbolic landscape. Barnes \& Nobles Books. 
de Certeau, M. (1984). The practices of everyday life. University of California Press.

Dickinson, G. (1997). Memories for sale: Nostalgia and the construction of identity in Old Pasadena. The Quarterly Journal of Speech, 83, 1-27. https://doi.org/10.1080/00335639709384169

Dickinson, G., Ott, B.L., \& Aoki, E. (2006). Spaces of remembering and forgetting: The reverent eye/I at the Plains Indian Museum. Communication and Critical/Cultural Studies, 3, 27-47. https://doi.org/10.1080/14791420500505619

Duszak, A. (2002). Us and others: Social identities across languages, discourses and cultures. John Benjamins. https://doi.org/10.1075/pbns.98

EPLO (2005, July 01). Konsultant soovitab Saaremaa püsiühenduseks silda. Eesti Päevaleht Online.

Foucault, M. (1980). Power/knowledge: Selected interviews and other writings, 1972-1977. C. Gordon (Ed.). Pantheon Books.

Foucault, M., \& Miskowiec, J. (1986). Of other spaces. Diacritics, 16(1), 22-27. https://doi.org/10.2307/464648

Giddens, A. (1991). Modernity and self identity: Self and society in the Late Modern Age. Polity.

Grossberg, L. (1996). The space of culture, the power of space. In I. Chambers \& L. Curti (Eds.), The post-colonial question: Common skies, divided horizons. Routledge. https://doi.org/10.4324/9780203297865

Grydehøj, A., \& Casagrande, M. (2020). Islands of connectivity: Archipelago relationality and transport infrastructure in Venice Lagoon. Area, 52(1), 56-64. https://doi.org/10.1111/area.12529

Häyrynen, M. (2004). Countryside imagery in Finnish national discourse. In H. Palang, H. Sooväli, H. Antrop \& M. Setten (Eds.), European rural landscapes: Persistence and change in a globalising environment (pp. 113-123). Kluwer. https://doi.org/10.1007/978-0-306$\underline{48512-1 \quad 7}$

Hong, G. (2020). Islands of enclavisation: Eco-cultural island tourism and the relational geographies of near-shore islands. Area, 52(1), 47-55. https://doi.org/10.1111/area.12521

Jameson, F. (1997). Postmodernism and consumer society. In P. Brooker \& W. Brooker (Eds.), Postmodern after-images: A reader in film, television and video (pp. 22-30). Arnold.

Jameson, F. (1997). Postmodernism and consumer society. In P. Brooker \& W. Brooker (Eds.), Postmodern after-images: A reader in film, television and video (pp. 22-30). Arnold.

Kaplan, R., \& Kaplan, S. (1989). The experience of nature: A psychological perspective. Cambridge University Press.

Kaur, E., Palang, H., \& Sooväli, H. (2004). Landscapes in change-opposing attitudes in Saaremaa, Estonia. Landscape and Urban Planning, 67, 109-120. https://doi.org/10.1016/s0169-2046(03)00032-x

Küchler, S. (1999). The place of memory. In A. Forty \& S. Küchler (Eds.), The art of forgetting. Berg.

Lefebvre, H. (1991). The production of space. Basil Blackwell.

Kuivjõgi, V. (2003, February 7). Tarvis: Keskerakond pole püsiühendust arutanud. Meie Maa. http://www.meiemaa.ee 
Kuivjõgi, V. (2007, February 7). Püsiühenduse otsuse teeb valitsus järgmisel aastal. Meie Maa. http://www.meiemaa.ee

Lember, A. (2007, February 2). Saarlased-rahvas, kes ei armasta koostööd. Oma Saar. http://www.omasaar.ee

Lember, A. (2007, March 5). Doktoritöö hoiatab sillaehituse eest. Oma Saar. http://www.omasaar.ee

Linehan, J.R., \& Gross, M. (1998). Back to the future, back to the basics: The sociology ecology of landscapes and the future of landscape planning. Landscape and Urban Planning, 50, 159-168. https://doi.org/10.1016/s0169-2046(98)00088-7

Leung, A., Tanko, M., Burke, M., \& Shui, C.S. (2017). Bridges, tunnels, and ferries: connectivity, transport, and the future of Hong Kong's outlying islands. Island Studies Journal, 12(2), 61-82. https://doi.org/10.24043/isj.24

Massey, D. (1995). The conceptualization of place. In D. Massey \& P. Jess (Eds.), A place in the world? Places, cultures and globalization (pp. 45-86). Open University.

Massey, D., \& Jess, P. (Eds.) (1995). A place in the world? Places, cultures and globalization. Oxford University Press.

Massey, D. (2005). For space. Sage.

MM (2002, May 9). Saaremaa püsiühendus koputab Euroopa toetusfondide uksele. Meie Maa. http://www.meiemaa.ee

MM (2003, May 22). Miks ja kas Saaremaa on atraktiivne? Meie Maa. http://www.meiemaa.ee

MM (2003, June 6). Erkki Raasuke: sild valmib enne Tallinna-Tartu kiirteed. Meie Maa. http://www.meiemaa.ee

MM (2004, May 22). Lõplik otsus püsiühenduse rajamise kohta tuleb teha järgmisel kevadel. Meie Maa. http://www.meiemaa.ee

MM (2006, June 6). Savisaar: Püsiühendusega tegelegu järgmised valitsused. Meie Maa. http://www.meiemaa.ee

MM (2007, March 27). Püsiühendus aastaks 2015. Meie Maa. http://www.meiemaa.ee

Merleau-Ponty, M. (1962). Phenomenology of perception. Routledge \& Kegan Paul.

Nakayama, T. K., \& Krizek, R. L. (1995). Whiteness: A strategic rhetoric. Quarterly Journal of Speech, 81, 291-309. https://doi.org/10.1080/00335639509384117

Neudorf, R. (2005, July 5) Saaremaa püsiühenduse eelistus kaldub sillale. Eesti Päevaleht Online.

O'Keeffe, T. (2007). Landscape and memory: Historiography, theory, methodology. In N. Moore \& Y. Whelan (Eds.), Heritage, memory and the politics of identity: New perspectives on the cultural landscape (pp. 3-18). Ashgate. https://doi.org/10.4324/9781315586694

Õunapuu, J. (2007, January 31). Püsiühendus mandriga või seltsimaja? Meie Maa. http://www.meiemaa.ee

Parts, P.K. (2004). Evaluation of landscape: Nature morte or Living Landscape? Akadeemia, 2, 227-253.

PM Online (2002, October 12). Saaremaa miljardisilla teekond joonistati merekaardile. Postimees. http://www.postimees.ee 
Raadik Cottrell, J. (2017). Island community: Identity formulation via acceptance through the environment in Saaremaa, Estonia. Island Studies Journal, 12(1), 169-186. https://doi.org/10.24043/isj.11

Raadik Cottrell, J. (2010). Cultural memory and place identity: Creating place experience. Doctoral dissertation. UMI Dissertation Publishing.

Raadik Cottrell, J., \& Cottrell, S.P. (2019). Sense of place predictors of perceived effects of a proposed island to mainland bridge on future experience, Island Studies Journal, 14(1), 2019, 187-204. https://doi.org/10.24043/isj.86

Raadik Cottrell, J., \& Cottrell, S.P. (2015). Sense-of-place influences on perceived environmental change effects on future holiday experiences to Saaremaa, Estonia. Scandinavian Journal of Hospitality and Tourism, 15(4), 425-446. https://doi.org/10.1080/15022250.2015.1024820

Ritivoi, A.D. (2002). Yesterday's self: Nostalgia and the immigrant identity. Rowman \& Littlefield.

Rossiter, N., \& Cooper, S. (2005). Processual media theory and the study of new media: towards a new research approach. In K. Kwansah-Aidoo (Ed.), Topical issues in communication and media research. Nova Science.

Sepp, A. (2004, October 06). Maavalitsuse tippametnik: sillaga kiirustada ei tasu. Meie Maa Online.

Simonsen, K. (2008). Place as encounters: Practice, conjunction and co-existence. In J. Bærenholdt \& B. Granås (Eds.), Mobility and place. Enacting Northern European peripheries (pp. 13-25). Ashgate. https://doi.org/10.4324/9781315595757

Sloop, J.M. (2004). Disciplining gender. University of Massachusetts Press.

Sooväli, H. (2004). Saaremaa Waltz: Landscape imagery of Saaremaa island in the $20^{\text {th }}$ century. Unpublished doctoral dissertation, University of Tartu, Tartu.

Stokols, D. (1981). Group X place transactions: some neglected issues in psychological research on settings. In D. Magnusson (Ed.), Towards a psychology of solutions: An international perspective (pp. 393-415). Lawrence Erlbaum.

Thrift, N. (2004). Intensities of feeling: towards the spatial politics of affect. Geografiska Annaler B, 86(1), 57-78. https://doi.org/10.1111/j.0435-3684.2004.00154.x

Thwaites, K. (2001). Experiential landscape place: an exploration of space and experience in neighbourhood landscape architecture. Landscape Research, 26(3), 245-255. https://doi.org/10.1080/01426390120068927

Tuan, Y. (1991). Language and the making of place: a narrative-descriptive approach. Annals of the Association of American Geographers, 81, 684-696. https://doi.org/10.1111/j.1467$\underline{8306.1991 . t b 01715 . \mathrm{x}}$

Tuan, Y. (1980). Rootedness versus sense of place. Landscape, 24(1), 3-8.

Tuan, Y. (1977). Space and place: The perspective of experience. University of Minnesota Press.

Viola, B. (1995). Reasons for knocking at an empty house: Writings 1973-1994. Thames and Hudson.

Viola, B. (2003). The passions. Getty Research Institute.

Volcic, Z. (2007). Yugo-nostalgia: Cultural memory and media in the former Yugoslavia. Critical Studies in Media Communication, 24(1), 21-38. https://doi.org/10.1080/07393180701214496 
Jana Raadik Cottrell \& Stuart P. Cottrell

Yell, S. (2005). Critical discourse analysis and social semiotics: Re-thinking text and discourse in media and communication research. In K. Kwansah-Aidoo (Ed.), Topical issues in communication and media research (pp. 9-23). Nova Science.

Wertsch, J. V. (2002). Voices of collective remembering. Cambridge University Press.

Zube, E.H., Sell, J.L., \& Taylor, J.G. (1982). Landscape perception: Research, application and theory. Landscape Planning, 9, 1-33.

Zhang, H., \& Grydehøj, A. (2020). Locating the interstitial island: Integration of Zhoushan Archipelago into the Yangtze River Delta urban agglomeration. Urban Studies, Epub ahead of print. https://doi.org/10.1177\%2F0042098020937987 